Disclosure of Interests: Lara Sanchez-Bilbao Grant/research support from: Pfizer, David Martinez-Lopez: None declared, Belén Atienza-Mateo: None declared, José Luis Martín-Varillas Grant/research support from: AbbVie, Pfizer, Janssen and Celgene, Speakers bureau: Pfizer and Lilly, Vanesa Calvo-Río Grant/ research support from: Abbvie, Lilly, UCB, MSD, Cellgene, Speakers bureau: Abbvie, Lilly, UCB, MSD, Cellgene, Rosalía Demetrio-Pablo: None declared, Monica Calderón-Goercke: None declared, D. Prieto-Peña: None declared, Iñigo González-Mazón: None declared, Elia Valls-Pascual Grant/research support from: Roche, Novartis, and AbbVie, Speakers bureau: AbbVie, Lilly, Pfizer, MSD, Novartis, Janssen, Bristol Myers Squibb, UCB Pharma, Beatriz Valls-Espinosa: None declared, Olga Maiz-Alonso: None declared, Ana Blanco Speakers bureau: Abbvie, Ignacio Torre-Salaberri: None declared, Verónica Rodriguez-Mendez: None declared, Ángel García-Aparicio: None declared, Raúl Veroz González: None declared, Vega Jovani: None declared, Diana Peiteado Grant/research support from: AbbVie, Lilly, MSD, and Roche, Speakers bureau: AbbVie, Roche, and MSD, Santos Castañeda: None declared, Margarita Sánchez-Orgaz: None declared, Eva Tomero Muriel: None declared, Francisco J. Toyos Sáenz de Miera: None declared, Valvanera Pinillos: None declared, Elena Aurrecoechea: None declared, Ángel Mora: None declared, Arantxa Conesa: None declared, Manuel Fernández: None declared, J. Antonio Troyano: None declared, Marcelino Revenga: None declared, J. Luis Hernández: None declared, Miguel A González-Gay Grant/ research support from: Pfizer, Abbvie, MSD, Speakers bureau: Pfizer, Abbvie, MSD, Ricardo Blanco Grant/research support from: AbbVie, MSD, and Roche, Speakers bureau: AbbVie, Pfizer, Roche, Bristol-Myers, Janssen, and MSD DOI: 10.1136/annrheumdis-2020-eular.3651

\section{FRI0505 \\ TOCILIZUMAB DISCONTINUATION AFTER REMISSION ACHIEVEMENT IN PATIENTS WITH ADULT STILL'S DISEASE}

H. Tamai ${ }^{1}$, Y. Kaneko ${ }^{1}$, T. Takeuchi ${ }^{1}{ }^{1}$ Keio University School of Medicine, Division of Rheumatology, Department of Internal Medicine, Tokyo, Japan

Background: The efficacy of tocilizumab, an interleukin (IL)-6 receptor inhibitor, has been proved in patients with adult Still's disease on suppressing systemic inflammation and decreasing glucocorticoid dose. However, whether tocilizumab can be discontinued after remission achievement is unclear.

Objectives: To clarify the possibility of tocilizumab discontinuation in patients with adult Still's disease who achieved remission with tocilizumab.

Methods: Consecutive patients with adult Still's disease diagnosed according to the Yamaguchi's criteria in our hospital from April 2012 until September 2019 were retrospectively reviewed. Patients who were in good control with tocilizumab were included in the analysis, and their clinical courses were collected from their medical charts. Patients were divided according to the presence of recurrence after tocilizumab discontinuation and compared.

Results: Among 42 patients with adult Still's disease who had a history of intravenous tocilizumab of $8 \mathrm{mg} / \mathrm{kg}$ use, 13 patients discontinued tocilizumab following a good disease control. During the mean observation period of 26.4 months, six patients $(46 \%)$ remained in remission while seven patients $(54 \%)$ developed recurrence after tocilizumab discontinuation. The sex and the mean observation period were not different between the patients with recurrence and those without ( $71 \%$ vs $50 \%, p=0.43 ; 27.3$ months vs 25.4 months, $p=0.93$, respectively), but the age at tocilizumab discontinuation tended to be higher in the recurrence group than the non-recurrence group (64.0 years vs 46.5 years, $p=0.08$ ). The disease activity including swollen joint counts and laboratory data at tocilizumab discontinuation were comparable between the two groups (serum ferritin levels, $88 \mathrm{ng} /$ $\mathrm{mL}$ vs $122 \mathrm{ng} / \mathrm{mL}, \mathrm{p}=0.67$ ). While the duration of tocilizumab use was not different between the two groups ( 29.4 months vs 39.5 months, $p=0.40$ ), the mean interval of tocilizumab infusion at tocilizumab discontinuation in the recurrence group was 3.6 weeks, shorter than the 6.7 weeks in the non-recurrence group $(p=0.03)$. The median dose of prednisolone at tocilizumab discontinuation was $5.0 \mathrm{mg} / \mathrm{day}$ in the recurrence group and $0.0 \mathrm{mg} /$ day in the non-recurrence group $(p=0.06)$. In the recurrence group, the duration from the last tocilizumab administration to recurrence was 7.8 months, and the median dose of prednisolone at recurrence was $5.0 \mathrm{mg} / \mathrm{day}$. Conclusion: Patients with adult Still's disease remaining in remission with a longer interval of tocilizumab administration and a lower dose of prednisolone was likely to succeed in withdrawal of tocilizumab.

Disclosure of Interests: Hiroya Tamai: None declared, Yuko Kaneko Speakers bureau: Dr. Kaneko reports personal fees from AbbVie, personal fees from Astellas, personal fees from Ayumi, personal fees from Bristol-Myers Squibb, personal fees from Chugai, personal fees from Eisai, personal fees from Eli Lilly, personal fees from Hisamitsu, personal fees from Jansen, personal fees from Kissei, personal fees from Pfizer, personal fees from Sanofi, personal fees from Takeda, personal fees from Tanabe-Mitsubishi, personal fees from UCB, Tsutomu Takeuchi Grant/ research support from: Eisai Co., Ltd, Astellas Pharma Inc., AbbVie GK, Asahi Kasei Pharma Corporation, Nippon Kayaku Co., Ltd, Takeda Pharmaceutical Company Ltd, UCB Pharma, Shionogi \& Co., Ltd., Mitsubishi-Tanabe Pharma Corp., Daiichi Sankyo Co., Ltd., Chugai Pharmaceutical Co. Ltd., Consultant of: Chugai
Pharmaceutical Co Ltd, Astellas Pharma Inc., Eli Lilly Japan KK, Speakers bureau: AbbVie GK, Eisai Co., Ltd, Mitsubishi-Tanabe Pharma Corporation, Chugai Pharmaceutical Co Ltd, Bristol-Myers Squibb Company, AYUMI Pharmaceutical Corp. Eisai Co., Ltd, Daiichi Sankyo Co., Ltd., Gilead Sciences, Inc., Novartis Pharma K.K., Pfizer Japan Inc., Sanofi K.K., Dainippon Sumitomo Co., Ltd. DOI: 10.1136/annrheumdis-2020-eular.3491

\section{FRI0506 \\ EFFICACY AND SAFETY OF CANAKINUMAB IN ADULT-ONSET STILL'S DISEASE: A SINGLE-CENTER REAL-LIFE EXPERIENCE}

A. Tomelleri ${ }^{1}$, C. Campochiaro ${ }^{1}$, G. De Luca ${ }^{1}$, N. Farina ${ }^{1}$, E. Baldissera ${ }^{1}$, G. Cavalli', L. Dagna'. ' San Raffaele Hospital, Milano, Italy

Background: The pro-inflammatory cytokine interleukin (IL)-1 has a central role in the pathogenesis of adult-onset Still's disease (AOSD), a rare auto-inflammatory condition. Anakinra, has been for years the cornerstone of IL-1-blocking therapy in AOSD. More recently, the monoclonal antibody canakinumab, a new agent blocking IL-1, has become available

Objectives: To describe our real-life experience with CNK in a cohort of AOSD patients from a single Italian Center

Methods: AOSD patients diagnosed according to Yamaguchi's criteria followed-up at our Autoinflammatory Unit and treated with CNK for at least 3 months were included. Demographic features, disease characteristics, reasons for CNK introduction, concomitant therapies, variation in systemic steroids dose, adverse events, and response to treatment were retrospectively evaluated. Non-parametric tests were used for statistical comparison

Results: 13 patients (5 women; median age 49 years, range 21-74), treated with subcutaneous CNK $4 \mathrm{mg} / \mathrm{kg}$ 4-weekly, were identified. Median disease duration before CNK introduction was 12 (6-240) months. After CNK introduction, 2 patients were followed-up for 18 months, 3 for 12 months, 6 for 6 months, 2 for 3 months. CNK was introduced as first-line biologic DMARD in 6 patients. The other 7 patients had been already treated with at least one other bDMARD, for a total of 15 treatment courses (7, anakinra, ANK; 4, tocilizumab; 4, TNF-inhibitors), with a median bDMARD therapy duration of 8 (4-178) months. Previous bDMARDs had been interrupted because of inefficacy ( 8 cases) or adverse events (AE, 7 cases); of the 7 ANK-treated patients, therapy interruption was due to inefficacy in 3 cases. At CNK introduction, 11 patients were on systemic steroid therapy, prednisone (PDN) equivalent dose $15(5-80) \mathrm{mg}$, and 10 were concomitantly receiving a conventional DMARD (7, methotrexate; 2 , colchicine; 1 , cyclosporine-A). Graphic 1 summarizes main clinical features at CNK introduction. After CNK start, a striking and rapid clinical response was observed, as demonstrated by a substantial decrease of modified Pouchot score and a normalization of acute phase reactants after only 3 months (see Table 1 for details). CNK showed also a significant steroid-sparing effect: median PDN dose was reduced to 7.5 (2.5-12.5)

Table 1. Disease activity and blood tests at canakinumab introduction and during follow-up

\begin{tabular}{|c|c|c|c|c|c|}
\hline $\begin{array}{l}\text { Daily prednisone dose } \\
\mathrm{mg}\end{array}$ & $\begin{array}{l}\text { Baseline } \\
(n=13)\end{array}$ & $\begin{array}{c}3 \text { months } \\
(n=13)\end{array}$ & $\begin{array}{c}6 \text { months } \\
(n=11)\end{array}$ & 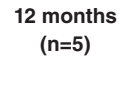 & $\begin{array}{c}18 \\
\text { months } \\
(n=2)\end{array}$ \\
\hline Pouchot score & $15(5-80)$ & $7.5(2.5-12.5)$ & $5(0-7.5)$ & $5(0-7.5)$ & 2.5 \\
\hline VAS pain & $3(2-5)$ & $1(0-2)$ & $0(0-1)$ & 0 & 0 \\
\hline $\begin{array}{l}\text { Erythrocyte } \\
\text { sedimentation rate } \\
\mathrm{mm} / \mathrm{h}\end{array}$ & $7(2-10)$ & $3(1-8)$ & $2(1-4)$ & $1(1-2)$ & 1 \\
\hline $\begin{array}{l}\text { C-reactive protein } \\
\mathrm{mg} / \mathrm{L}\end{array}$ & $42(8-120)$ & $21(2-69)$ & $13(2-55)$ & $14(2-41)$ & 11 \\
\hline $\begin{array}{l}\text { Ferritin } \\
\mathrm{ng} / \mathrm{mL}\end{array}$ & $20.8(3-180)$ & $3.1(0.5-22.5)$ & $1.6(0.5-8.4)$ & $1(0.3-6.3)$ & 0.5 \\
\hline \multirow{2}{*}{$\begin{array}{l}\text { Hemoglobin } \\
\mathrm{g} / \mathrm{dL}\end{array}$} & $379.5(161-914)$ & $282(82-552)$ & $215(34-464)$ & $177(77-401)$ & 199 \\
\hline & $13.1(9.4-15.7)$ & $\begin{array}{c}13.2 \\
(10.7-15.3)\end{array}$ & $\begin{array}{c}13.8 \\
(11.5-15.5)\end{array}$ & $\begin{array}{c}13.9 \\
(11.3-14.3)\end{array}$ & 13.5 \\
\hline
\end{tabular}

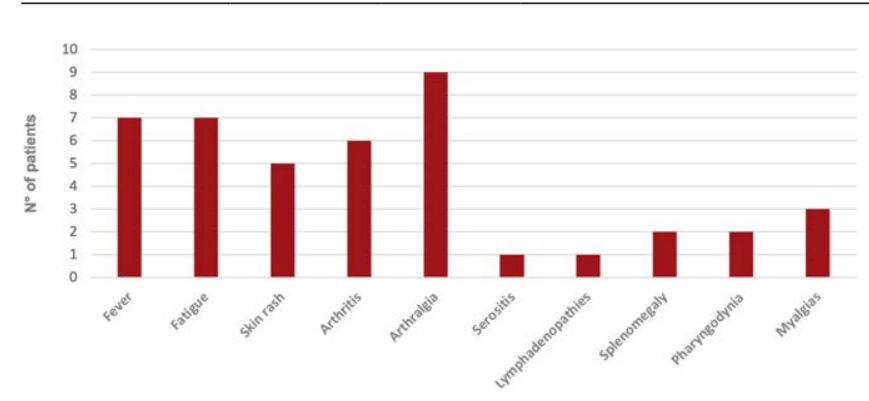

Figure 1. Graphic 1 Main clinical features at canakinumab introduction 